\title{
The role of government policy in entrepreneurship development
}

\author{
Nkem Okpa Obaji ${ }^{1,}$, , Mercy Uche Olugu ${ }^{2}$ \\ ${ }^{1}$ Fakulti of Management, Univerisiti Teknologi Malaysia, 81310 UTM, Skudai, Johor, Malaysia \\ ${ }^{2}$ Department of Statistics, Federal School of Statistics, Ibadan, National Bureau of Statistics, Nigeria
}

\section{Email address:}

amazonsng@yahoo.com (N. O. Obaji),olugumercy@yahoo.com (M. U. Olugu)

\section{To cite this article:}

Nkem Okpa Obaji, Mercy Uche Olugu. The Role of Government Policy in Entrepreneurship Development. Science Journal of Business and Management. Vol. 2, No. 4, 2014, pp. 109-115. doi: 10.11648/j.sjbm.20140204.12

\begin{abstract}
This paper aims to develop a conceptual framework that examines the role government policy plays in the development of entrepreneurship and its impact on economic development. The study builds on existing literature on entrepreneurship, economic development and government policy as it relates to entrepreneurial practices. The outcomes of literature review propose two hypotheses. Integrating entrepreneurship practices with economic development, with government policy intervening, a framework is developed. For the reason that entrepreneurship is a part of economic development strategy employed by several countries globally to achieve macro-economic benefits. The framework provides a starting point for researchers and practitioners to further examine entrepreneurship policies and practices. For researchers, the framework clarifies the determining attributes of entrepreneurship, government policy and economic development dimensions and their proposed relationships. For practitioners, the framework can be used to gain an understanding of the role of government policy on entrepreneurship development as well as economic development.
\end{abstract}

Keywords: Entrepreneurship, Economic Development, Entrepreneurs, Government Policy, Moderator

\section{Introduction}

It is reported in entrepreneurship literature that several variants of definition of entrepreneurship concept exist [1] for the reason that entrepreneurship epitomises a complex phenomenon, being examined as a process, a resource or a state-of-being [2]. In line with this, researchers classify entrepreneurship into three main groups [2]. The groups are behavioural definitions (e.g., Schumpeter, Kirzner); occupational definitions (e.g., Evans and Jovanovic); synthesis definitions (e.g., Gries and Naudé). This study will adopt the behavioural definition of Schumpeter. Schumpeter [3], defined entrepreneurship, as making new combinations which include the introduction of new goods, new methods of production, opening of new markets, new sources of supply and new organizations.

The importance of entrepreneurship development in several economies globally cannot be overemphasized; as such majority of countries worldwide have established programmes to support entrepreneurship within their communities [4]. One of the support schemes that spur entrepreneurship development is the business incubator and the policy tool to achieve this is the business incubation initiative. Economic development has been defined by [5] as the method of creating wealth by the gathering of human, financial, capital, physical and natural resources to produce marketable goods and services. Rice and Matthews [6]reported that the main goal of business incubation initiative is entrepreneurship development. In other words an incubator's main goal is to produce successful firms that will leave the programme financially viable and freestanding[7].

Business incubators within such programmes serve as places where entrepreneurs receive value-added support and access to critical tools, information, education, contacts, capital, and other resources that may otherwise be unaffordable, inaccessible, or unknown to them[7]. These resources can be made available by a responsive government to fill gaps that have been identified in entrepreneurship support activities. Al-Mubaraki, Al-Karaghouli and Busler [8]stated that economic development is one of the objectives that drive each incubator.

Fukugawa [9] described entrepreneurship to mean the 
recognition or creation of business opportunities and the exploitation of the opportunities through new firm creation. Meanwhile entrepreneurship literature acknowledges the individual role in the entrepreneurial process both in developed and developing countries [10]. Shane [11] reported that certain psychological dimensions are vital for effective functioning as an entrepreneur. Some of the attributes include risk taking tendency, differential access to scarce and expensive resources, and leadership quality among others.

Ahmed and Nwankwo [12] reported that several literature concerning the diminished ability of African nations to register real increases in employment abound. Furthermore, despite the privatization and deregulation initiative of the 1980 s as well as its attendant huge corruption of the process implementation, the continent still refuses to reduce its unemployment. They further claimed that, the only way out for the totality of the employable people in these countries is through entrepreneurship initiative. Against this background the role of entrepreneurship in the economies of most countries has been acknowledged in the entrepreneurship literature. Entrepreneurs variously contributed to the economic development of nations through job creation, SME development as well as commercialization of research and development (R\&D) products and technology transfer [13]. However, this group of entrepreneurs may have difficulty in accessing the various factors of production as well as user friendly enactments related to entrepreneurship [14, 15] Literature related to entrepreneurship has been extensively studied, however, there is still little or no study in the area of government policy moderating the relationship between entrepreneurship and economic development.

Other studies in entrepreneurship and economic development have focused on the role of government as the lead entity in the entrepreneurial development study. Thus, this study fills the gap by proposing a study where government policy moderates the relationship between entrepreneurship and economic development. Against this backdrop, this study seeks to identify the salient role of government enactment towards entrepreneurship in particular and the importance attached to the other factors of production in general. In the context of this study, three variables will be studied. They include entrepreneurship which includes start-up motive, creativity and innovativeness and risk taking. The second variable is the economic development which is composed of job creation, SME development and Wealth creation. The third variable is government policy which consists of policy implementation, supportive government policies and government funding. In this paper we seek to contribute to the entrepreneurship literature. Specifically, this paper aims at examining the importance of government policy in the entrepreneurial development.

This paper is structured as follows: in the following section (2), literature related to entrepreneurship as well as government policy is reviewed. This is followed by conceptual framework and hypotheses development in section 3. Section 4 is on research procedures while section 5 dwells on conclusion and implication.

\section{Literature Review}

It has been established that entrepreneurship is a very vital ingredient for job creation as well as economic development [16] as the success of income generation for the major group of both rural and urban inhabitants without recognized paid job highly depends on entrepreneurship [17]. The relationship between entrepreneurship and economic development has been studied extensively both at the local, state and federal levels [18]. Kumar and Liu [19] study reveal that entrepreneurial sector contribution to employment and GDP is on the increase. For this reason [20] suggested that governments should minimize the constraints on entrepreneurship.

In the case of government support policies, it is assumed that since government is in the lead for entrepreneurial development, it should provide the much needed resources within its capability. Such resources include provision of environment conducive to business that will highly promote entrepreneurship. Government policy in this context is any course of action which aims at regulating and improving the conditions of SMEs in terms of supportive, implementation and funding policies by the government. Based on this definition, government policy as it relates to entrepreneurial practice is targeted at encouraging entrepreneurship by making a favorable environment for the entrepreneurs. This, it does through enactment of guidelines that will regulate entrepreneurial activity generally for the reason that entrepreneurship is the bedrock of a nation's path to industrialization. Furthermore, government needs to enact policies that would be user friendly to the entrepreneurs. Pals [21] argued that there is a need for government policies as they relate to entrepreneurship to be successfully implemented irrespective of which administration is in power in order to achieve the goals of the guideline which often times is always lacking.

Government of most countries especially developing countries have in the past invested so much efforts and resources in establishing policies intended to uplift entrepreneurship [22]. Cases in point are in China, Brazil, Saudi Arabia, Malaysia and Nigeria [13].

The Chinese government has made concerted efforts through policies and resources on the development of high technology businesses [23]. The Brazilian entrepreneurship movement has established very fast as a result of government policies geared towards developing the low-tech businesses as well as high technological oriented firms [24]. In a recent study, [25] reported that the Kingdom of Saudi Arabia in 2010 established a ten year entrepreneurship efforts and innovation. The intention was a strategy to put the Kingdom at equal pedestal with high economic competitive nations globally.

In the context of Malaysia, in its bid to develop Malaysia through the growth of technology entrepreneurship, the government has guided in setting up of various technology funding organizations with the aim of giving full support to technology businesspersons [26]. This include the establishment of venture capital firms by the government with 
the intent of encouraging investments in high growth firms for the reason that they find it difficult to raise adequate financing at the early stage growth [26].

In Nigeria, different administrations at various times have geared their efforts towards developing its entrepreneurship. Several developmental and financial assistance instruments were employed [22]. However, such government ingenuities were terribly unsuccessful as a result of overbearing bureaucratic procedures, corruption, insufficient and ineffectual infrastructural amenities [17]. They mentioned inconsistent government policies as one of the challenges faced by entrepreneurs in Nigeria. Their argument is based on the fact that before entrepreneurs succeed in Nigeria, they must have political clout as well as massive resources to be able to influence government laws. Thus as start-up entrepreneurs, those two (political clout and huge financial resources) are lacking. Lee and Osteryoung [27] reported that the capability of business owner to influence government policy is related to the success of entrepreneurial activities. Ihugba, Odii and Njoku [17] argued that even though Nigerians are possibly one of the most entrepreneurial people globally, government is not doing enough to encourage entrepreneurs through policies. One of their key recommendations was for government to make available the enabling environment for private sector led investment through the delivery of suitable infrastructural amenities. Sriram and Mersha [28] discussed the factors that contribute to success of new business venture in Africa especially the start-up. They reported that effective government policy is very crucial in encouraging successful business enterprises.

Several studies have been conducted with regards to the role of government policies in the development of entrepreneurship generally $[16-18,29]$. Their various contributions have been contradictory as well as supporting. For example while $[18,29]$ are in support of government policies in encouraging entrepreneurship, $[16,17]$ are on the contrary. A case in point is Friedman's study finding which shows that perceived government effectiveness was significantly negatively related to entrepreneurship on a national level. On the other hand, [18] observed that government policy add vigorously to the development of an institutional setting that encourages productive entrepreneurship. He however added that the relationship between policy and entrepreneurial activity varies across countries.

Literature from several studies have shown that government policy is positively related to entrepreneurship [29, 30]. On the contrary, other studies also found government policy to be negatively related to entrepreneurship $[16,17]$. Consequently, the above show that a contradiction in the role of government policy towards encouraging entrepreneurship especially in the developing countries. Based on this background, this study used government policy as a moderator as stated in [31]. Therefore government policy moderated the relationship between Entrepreneurship and Outcome.

From the foregoing discussions, it is pertinent to note that there is still gap in the literature related to entrepreneurship and economic development. This study contributes to the body of knowledge by using government policy to moderate the relationship between entrepreneurship and economic development.

\section{Conceptual Framework and Hypotheses Development}

It has been established that entrepreneurship is a very important component of job creation as well as economic development [16] as the success of income generation for the major group of both rural and urban inhabitants without recognized paid job greatly depends on entrepreneurship [17].

On the basis of a review of literature, we discover three elements that serve as contributing attribute to entrepreneurship: creativity and innovativeness, risk taking and start-up motive.

\subsection{Creativity and Innovativeness}

One of the first writers to present the innovation function into the entrepreneurial process is [3]. Kibassa [32] postulates that innovativeness is the constituent of human disposition, which assists entrepreneurs in nurturing innovations in their company. Recently, OECD as well as European Union has in strong terms recommended innovation as a strategic driver for economic development [33].

Wonglimpiyarat [34] stated that productivity, standard of living as well as sustainable economic development may be enhanced through technology innovations. Innovation plays a very crucial role in attaining economic development by concentrating on science and technology-based knowledge [35]. Ajagbe and Ismail [36] reported that innovation has become an indispensable stimulant for nation's development irrespective of whether the country belongs to industrialized or developing. The innovativeness of an entrepreneur may perhaps tend to improve towards the attainment of economic development through the development of SMEs. These SMEs within the locality will employ more people thereby increasing the wealth of the locality. In sum, Innovative based businesses play a substantial part in economic development by employment generation, wealth creation [37] new markets development as well as accelerating technological development [38].

\subsection{Start-Up Motive}

Start-up motive consists of those entrepreneurial intentions which made the business person to be an entrepreneur. Several factors may perhaps be attributed to this, which include the zeal to be innovative, to build a successful organization, using specific talents effectively, to be one own boss and need for independence among others. When the start-up firm has motive to commence a business, his intention will be to build a successful organization in the future. The outcome of building a successful organization will lead to economic development through employment formation, SME development as well as wealth creation. 


\subsection{Risk Taking}

Risk taking is defined as the practice of doing things that involve risks for a reward [39]. Building upon this concept, different definitions and concepts regarding risk taking are available to date [40]. In entrepreneurship literature, [41] maintained that the notion of assuming risks and uncertainty began in the 18th century through economic theory which was advanced by Cantillon in 1931. Building on the work of Cantillon, [40], stated that the key element that distinguishes an entrepreneur from a hired employee was uncertainty and the risk embedded in self-employment. In line with this concept, [42] described a risk-taker as the individual who pursues a business idea with the possibility to succeed. When an entrepreneur succeeds, there is tendency to expand his business and engage more people in employment, thereby creating wealth within the locality and accordingly economic development.

Entrepreneurship helps to bring about economic development through wealth creation, employment creation, and enhancement of the competitiveness of the existing SMEs When there is employment generation as well as increase in the number of entrepreneurs or SMEs, economic development or growth usually takes place. When there are many SMEs in the locality, there is the tendency for local people to be employed by these firms. In line with this, [43] described entrepreneurship development as a key enabler of economic development. Furthermore, it is generally acknowledged by numerous scholars that entrepreneurship is the engine of economic development [4, 44, 45].

Objective: To examine the relationship between entrepreneurship and economic development.

Based on the above discussions, it is hypothesized that:

H1: There is a positive relationship between entrepreneurship and economic development

Three elements were also found in the course of literature survey to be contributing attribute to economic development. They are supportive government policies, policy implementation and government funding.

\subsection{Supportive Government Policies}

As government is in the lead of the establishment, sponsorship and administration of most support programmes especially in the developing countries, a proclamation from the government as it relates to entrepreneurship will go a long way to ensuring the sustainability and positive entrepreneurial practice. Thus, it will bring economic development through SME development, job creation as well as wealth creation. A number of studies have been conducted with regards to the role of government policies in the development of entrepreneurship generally [16-18, 29] and its impact on economic development.

\subsection{Policy Implementation}

Policy charts a course and provides a blue-print for the implementation of government programme. It guides the thinking of government in the implementation of a programme and defines its direction. A case in point is government and administration of public institutions in Nigeria which is fundamentally based on policies drawn-up by the government, often times these policies are beautiful and achievable on paper, however, there has always been a problem with implementing these policies owing to several factors of governance and willpower to accomplish them.

\subsection{Government Funding}

Accessibility of monetary services is one of the significant factors for the continued existence of majority of the newly formed firms as well as an essential element in entrepreneurship practice. Shuo [46] reports that government use direct subsidies, tax incentives and government procurement to inject large amount of resources to the entrepreneurial process. For the attainment of economic development through entrepreneurship, there should be a funding pattern by which the support programme will be constantly funded. The programme should be funded based on the policy document establishing the assistance programme.

The various research contributions of government policy have been contradictory as well as supporting. Studies by [29, 30] have shown that government policy is positively related to entrepreneurship. On the contrary, other studies also found government policy to be negatively related to entrepreneurship [16, 17]. Consequently, the above discourses show that a contradiction in the role of government policy towards encouraging entrepreneurship especially in the developing countries. When there are many SMEs in the locality, there is the tendency for local people to be employed by these firms that have been standing on their own as a result of government support programme.

Objective: To examine the moderating effect of government policy between entrepreneurship and economic development.

Consequently, this study hypothesized that:

$H 2$ : Government policy moderates the relationship between Entrepreneurship and economic development.

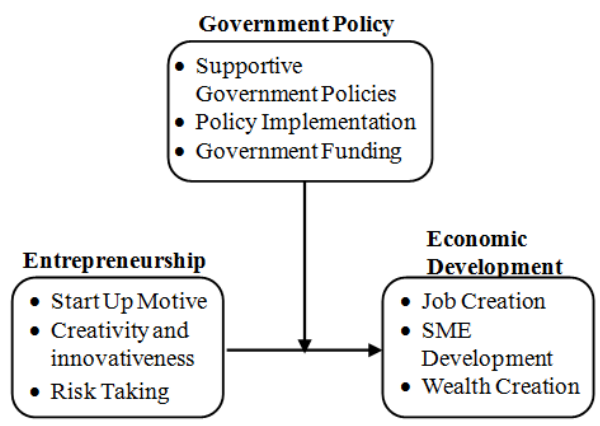

Figure 1. Conceptual Framework.

Figure 1 depicts the proposed conceptual framework that incorporates the entrepreneurship and economic development through efficient and user friendly government policies. The outcomes of a literature review propose two hypotheses. There are three measures of entrepreneurship which include start-up motive, creativity and innovativeness and risk taking. Government policy is composed of policy implementation, 
supportive government policies and funding. Economic development is composed of three measures namely, job creation, SME development and wealth creation.

The context of the framework as shown in Figure 1 placed an importance in the role of government policy in determining economic development. Government policy is seen as an anchor to all other factors which are also essential and paramount to any entrepreneurial scheme. The issue here is that with the presence of government policy moderating on the relationship between the entrepreneurship and the economic development there is likelihood of a positive outcome of SME development, wealth creation and job creation within the locality.

\section{Procedures}

In corroborating this conceptual model, the process called for justification of measurements, structural model as well as direction for future scholarly work. Consequently, a quantitative research method will be utilized in order to improve the reliability of the measurements. This scholarly work will adopt the established scales instrument for assessing entrepreneurship, economic development and government policy. In line with this, the questionnaire adopted will be applied as the data collection instrument in this study. This is in conformity with [47] who contended that questionnaire is employed when quantifiable evidence about the population is judged to be in accordance with approved usage as an origin of evidence.

The analysis related to the measurement and structural model will be carried out by utilizing the structural equation modeling (SEM) approach and employing the Partial Least Squares (PLS) techniques. The reliability analysis can be accomplished on all the variables (entrepreneurship, economic development and government policy) in the research model of this study to assess the degree of internal consistency between measurements of multiple variables, which is interpreted like a cronbach's alpha.

\section{Conclusion and Policy Implication}

From the foregoing, it can be seen that government of several countries view entrepreneurship as the bedrock of industrialisation of their economy and thus encourage entrepreneurship. However, [48] argued that policy makers had better discontinued subsidizing the establishment of the generic start-up; instead consideration should be on businesses with growth potential. His argument relates to how these policies direct people to commence marginal companies that are likely to be unsuccessful or have slight economic effect as well as making small employment. Nonetheless, entrepreneurial success of any nation is largely dependent on the policy behavior of the government. Since most governments especially in the developing countries are striving to achieve economic development, they are always bringing out supportive policy programmes in different forms, e.g. infrastructural, financial, and fiscal among others. This scholarly work fills the literature gap by linking the antecedents of entrepreneurship to economic development while government policy intervenes in the relationship.

\subsection{Policy Implications}

This study offers several contributions to the literature in the field of entrepreneurship and strategic management. To start with, it improves an understanding of the role or importance of government policy to entrepreneurship development. Secondly, this study confirms the research conducted by [29, 30, 49] on the importance of government policies to business performance. The importance of government policy towards entrepreneurship cannot be overemphasized since it in turn shapes the institutional environment in which entrepreneurial decisions are made [18].

\section{Acknowledgements}

The authors would like to thank Ringa Kaingu Ringa and Umar Saganuwan for the formatting and peer review of the manuscript respectively.

\section{References}

[1] Toma, S.-G., Grigore, A.-M., and Marinescu, P., Economic Development and Entrepreneurship. Procedia Economics and Finance, 2014. 8: p. 436-443.

[2] Naudé, W.A., Entrepreneurship and economic development: Theory, evidence and policy. 2013, IZA Discussion Paper.

[3] Schumpeter, J.A., The theory of economic development: An inquiry into profits, capital, credit, interest, and the business cycle. Vol. 55. 1934: Transaction Publishers.

[4] Gangi, Y.A. and Timan, E., An empirical investigation of entrepreneurial environment in Sudan. World Journal of Entrepreneurship, Management and Sustainable Development, 2013. 9(2/3): p. 168-177.

[5] Al-Mubaraki, H.M. and Busler, M., Business Incubation as an Economic Development Strategy: A Literature Review. International Journal of Management, 2013. 30(1): p. 362-372.

[6] Rice, M.P. and Matthews, J.B., Growing New Ventures, Creating New Jobs: Principles and Practices of Successful Business Incubation. 1995, Westport, CT: Quorum Books.

[7] NBIA, What is Business Incubation. 2009, National Business Incubation Association: Athens Ohio.

[8] Al-Mubaraki, H., Al-Karaghouli, W., and Busler, M. The Creation of Business Incubators in Supporting Economic Developments. in European, Mediterranean \& Middle Eastern Conference on Information Systems 2010 (EMCIS2010). 2010.

[9] Fukugawa, N., Which Factors do Affect Success of Business Incubators. Journal of Advanced Management Science, 2013. 1(1).

[10] Alagbaoso, M., Myres, K., and Teresa, C. Biotechnology Entrepreneurship in South Africa and Brazil. in 27th International Business Research Conference. 2014. Toronto, Canada: Ryerson University. 
[11] Shane, S.A., A general theory of entrepreneurship: The individual-opportunity nexus. 2000: Edward Elgar Publishing.

[12] Ahmed, A. and Nwankwo, S., Entrepreneurship development in Africa: an overview. World Journal of Entrepreneurship, Management and Sustainable Development, 2013. 9(2/3): p. 82-86.

[13] InfoDev, Global Good Practice in Incubation Policy Development and Implementation. 2010, The World Bank: Washington, DC.

[14] Adelowo, C.M., Olaopa, R.O., and Siyanbola, W.O., Technology Business Incubation as Strategy for SME Development: How Far, How Well in Nigeria? Science and Technology, 2012. 2(6): p. 172-181.

[15] Ajagbe, A.M., et al., Selection criteria for financing young firms using debt options and breakthroughs, in Frontiers of Business, Management and Economics: An Interdisciplinary Collection of Managerial Research Findings M. Nejati, Editor. 2013, Universal Publishers: Boca Raton, Florida. p. 265-269.

[16] Friedman, B.A., The relationship between governance effectiveness and entrepreneurship. International Journal of Humanities and Social Science, 2011. 1(17): p. 221-225.

[17] Ihugba, O.A., Odii, A., and Njoku, A., Theoretical Analysis of Entrepreneurship Challenges and Prospects in Nigeria. International Letters of Social and Humanistic Sciences, 2014. 5: p. 21-34.

[18] Minniti, M., The role of government policy on entrepreneurial activity: productive, unproductive, or destructive? Entrepreneurship Theory and Practice, 2008. 32(5): p. 779-790.

[19] Kumar, S. and Liu, D., Impact of globalisation on entrepreneurial enterprises in the world markets. International Journal of Management and Enterprise Development, 2005. 2(1): p. 46-64.

[20] Acs, Z.J., et al., The missing link: The knowledge filter and entrepreneurship in endogenous growth. 2004.

[21] Pals, S., Factors Determining Success/Failure in Business Incubators: A Literature Review of 17 Countries. 2006, Worcester Polytechnic Institute.

[22] Oni, E.O. and Daniya, A., Development of small and medium scale enterprises: The role of government and other financial institutions. Arabian Journal of Business and Management Review, 2012. 1(7): p. 16-29.

[23] Cullen, M., Calitz, A., and Chandler, L., Business incubation in the eastern Cape: a case study. International Journal for Innovation Education and Research, 2014. 2(05): p. 76-89.

[24] Etzkowitz, H., Incubation of incubators: innovation as a triple helix of university-industry-government networks. Science and Public Policy, 2002. 29(2): p. 115-128.

[25] Salem, M.I., The Role Of Business Incubators In The Economic Development Of Saudi Arabia. International Business \& Economics Research Journal (IBER), 2014. 13(4): p. 853-860.

[26] Ajagbe, M.A. and Ismail, K., Factors influencing venture capital assessment of high growth companies in Malaysia. International Journal of Entrepreneurship and Small Business, 2014. 21(4): p. 457-494.

[27] Lee, S.S. and Osteryoung, J.S., A Comparison of Critical Success Factors for Effective Operations of University
Business Incubators in the United States and Korea. Journal of Small Business Management, 2004. 42(4): p. 418-26.

[28] Sriram, V. and Mersha, T., Stimulating entrepreneurship in Africa. World Journal of Entrepreneurship, Management and Sustainable Development, 2010. 6(4): p. 257-272.

[29] Mason, C. and Brown, R., Creating good public policy to support high-growth firms. Small Business Economics, 2011. 40(2): p. 211-225.

[30] Greene, F., Should the focus of publicly provided small business assistance be on start-ups or growth businesses? 2012, Ministry of Economic Development, New Zealand.

[31] Baron, R.M. and Kenny, D.A., The moderator-mediator variable distinction in social psychological research: Conceptual, strategic, and statistical considerations. Journal of personality and social psychology, 1986. 51(6): p. 1173.

[32] Kibassa, F.M., Small Business Research: Upon Finding Definitions of Entrepreneurship, Entrepreneur and Small Firms. European Journal of Business and Management, 2012. 4(15): p. 158-167.

[33] Mazzucato, M., The entrepreneurial state: Debunking public vs. private sector myths. 2013: Anthem Press.

[34] Wonglimpiyarat, J., Government programmes in financing innovations: Comparative innovation system cases of Malaysia and Thailand. Technology in Society, 2011.33(1): p. 156-164.

[35] Thiruchelvam, K., et al., Towards effective policies for innovation financing in Asia financing innovation, the experience of Malaysia. 2010, Working Paper Report Submitted to the IDRC Project.

[36] Ajagbe, A.M. and Ismail, K., The Financing of early staged technology based firms in Malaysia. Middle-East Journal of Scientific Research, 2013. 18(5): p. 697-707.

[37] Scillitoe, J.L. and Chakrabarti, A.K., The role of incubator interactions in assisting new ventures. Technovation, 2010. 30(3): p. 155-167.

[38] Somsuk, N. and Laosirihongthong, T., A fuzzy AHP to prioritize enabling factors for strategic management of university business incubators: resource-based view. Technological Forecasting and Social Change, 2014. 85: p. 198-210.

[39] Stewart Jr, W.H. and Roth, P.L., Risk propensity differences between entrepreneurs and managers: a meta-analytic review. Journal of applied psychology, 2001. 86(1): p. 145.

[40] Isaga, N., Entrepreneurship and the growth of SMEs in the furniture industry in Tanzania. 2012.

[41] Kirby, D.A., Entrepreneurship. 2003, Maidenhead: McGraw-Hill Education.

[42] Chell, E., Haworth, J.M., and Brearley, S., The entrepreneurial personality: Concepts, cases and categories. 1991: Routledge London.

[43] Davari, A., et al., Assessing the forward-looking policies of entrepreneurship development in Iran. World Journal of Entrepreneurship, Management and Sustainable Development, 2012. 8(1): p. 60-70.

[44] Gómez-Haro, S., Aragón-Correa, J.A., and Cordón-Pozo, E., Differentiating the effects of the institutional environment on corporate entrepreneurship. Management Decision, 2011. 49(10): p. 1677-1693. 
[45] Bosma, N. and Schutjens, V., Mapping entrepreneurial activity and entrepreneurial attitudes in European regions. International Journal of Entrepreneurship and Small Business, 2009. 7(2): p. 191-213.

[46] Shuo, L., Study on the function of government in the innovation and development process for SMEs in China. 2014.

[47] Ticehurst, G. and Veal, A., Business research methods: a managerial approach. 2000, Australia: Pearson Education.
[48] Shane, S., Why encouraging more people to become entrepreneurs is bad public policy. Small business economics, 2009. 33(2): p. 141-149.

[49] Ng, P.Y., Characterising High Growth Firms: Perspectives from the Asia-Pacific Region. 2013. 